\title{
"Sign of the kiss" in dermatitis caused by vesicant beetles ("potós" or Paederus sp.)
}

Vidal Haddad Junior ${ }^{1}$

\begin{abstract}
The cosmopolitan beetles of the Paederus genus (potós) cause a severe dermatitis when the insect is crushed against the skin of exposed areas (the cervical region is the most affected). Toxins (pederin and others) from the hemolymph of the insect cause plaques and/or bizarre, linear lesions with erythema, edema, blisters, pustules, crusts and exulcerations. There may be a burning sensation and severe conjunctivitis. Lesions disappear after 10 days and may leave hyperchromic macules. Treatment is made with topical corticosteroids and intensive washing.
\end{abstract}

Keywords: Poisonous animals, Beetles; Dermatitis; Poisons

Poisonous animals can provoke envenomations humans by passive release of toxins. Some beetles (Coleoptera) may produce and/or store vesicant toxins, such as the genera Epicauta, Lytta (Spanish fly) and Paederus. ${ }^{1}$

The Paederus beetles or "potós" cause a severe dermatitis, especially in warm climate such as the Midwest and Northeast Brazil (Figure 1). ${ }^{2,3}$ These insects are cosmopolitan and were first associated with vesicular dermatitis by Pirajá da Silva in Brazil. ${ }^{4}$ The animal is crushed against the skin of exposed areas (the cervical region is the most affected) and toxins (such as pederin and others), which are present in the hemolymph of the insect, cause plaques

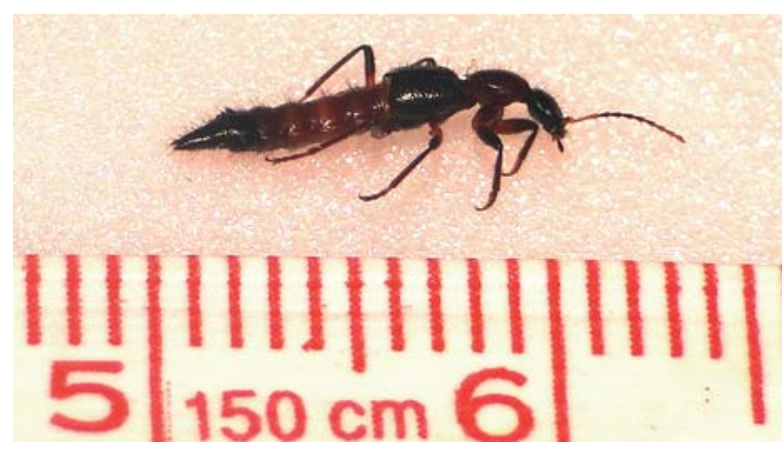

Figure 1: Paederus sp., the "potó". This beetle is the most common vesicant beetle around the world and/or linear lesions with erythema, edema, blisters, pustules, crusts and exulcerations. There may be a burning sensation and severe conjunctivitis.

Approved by the Advisory Board and accepted for publication on 08.01.2014. * Study conducted at the Botucatu Medical School, Sao Paulo State University Julio de Mesquita Filho (FMB-Unesp), Botucatu (SP), Brazil.
Conflict of interest: None

Financial funding: None

Sao Paulo State University Julio de Mesquita Filho (Unesp), Botucatu (SP), Brazil. 


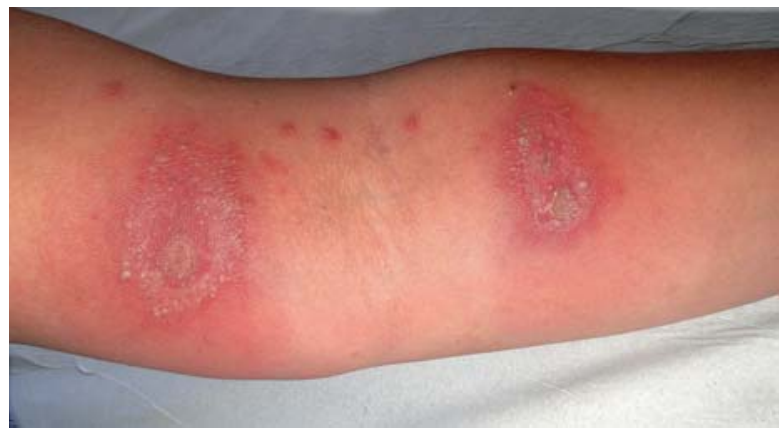

FIGURE 2: Vesicant lesions in an area of healthy skin juxtaposed to damaged skin, which reproduces the lesions

Distribution is bizarre. Lesions disappear after about 10 days and may leave hyperchromic macules. In skin folds, the "sign of the kiss" can occur in an area of healthy skin juxtaposed to damaged skin. Vesicant lesions are reproduced due the contact with the toxins (Figure 2).

The "potó" dermatitis can be confused with herpes simplex, varicella-zoster, contact dermatitis or phytophotodermatitis. ${ }^{1}$ Dermatologists should suspect the dermatitis in individuals with vesicles or pustules, who were in hot areas near lampposts, as in this case, in which a young woman slapped her arm as she "felt an insect" crawling on it. The treatment comprises washing with boric water, topical corticosteroids and antibiotics if bacterial infection is present. $^{1}$ In severe cases with multiple contacts, systemic corticosteroid therapy is indicated. ${ }^{1}$

\section{REFERENCES}

1. Cardoso JLC, Haddad Jr V. Acidentes por Coleópteros vesicantes e outros artrópodos. In: Cardoso JLC, Franç̧a FOS, Wen FH, Malaque CMS, Haddad Jr V, editores. Animais peçonhentos no Brasil: biologia, clínica e terapêutica dos acidentes. 2. ed. São Paulo: Editora Sarvier ; 2009. p. 274-280.

2. $\quad$ Pirajá da Silva M. Le Paederus columbinus est vésicant. Arch Parasitol.1912;15:429-31.

3. Cardoso AEC, Lima-Filho MR. Vesicular dermatitis induced by Paederus: an outbreak in Northeastern Brazil. An Bras Dermatol. 1986;61:173-6.

4. Diógenes MJN. Dermatite de contato pela pederina, estudo clínico e epidemiológico no Estado do Ceará, Brasil. Rev Inst Med Trop São Paulo. 1994;36:59-65.

How to cite this article: Haddad Jr V. "Sign of the kiss" in dermatitis caused by vesicant beetles (Paederus sp. or "potós"). An Bras Dermatol. 2014;89(6):996-7.

\author{
MAILING ADDRESS: \\ Vidal Haddad Junior \\ Caixa Postal 557 \\ 18618-970 - Botucatu - SP \\ Brazil \\ E-mail: haddadjr@fmb.unesp.br
}

